\title{
STin2 VNTR polymorphism in the serotonin transporter gene and migraine: pooled and meta-analyses
}

\author{
Markus Schürks • Pamela M. Rist • \\ Tobias Kurth
}

Received: 22 April 2010/Accepted: 28 May 2010/Published online: 29 June 2010

(C) Springer-Verlag 2010

\begin{abstract}
Data on the association between the SLC6A4 STin2 VNTR polymorphism and migraine are conflicting. To perform pooled and meta-analyses, we searched for studies published until September 2009 using electronic databases (MEDLINE, EMBASE, Science Citation Index) and reference lists of studies. Assessment for eligibility and extraction of data was performed by two independent investigators. We extracted allele and genotype frequencies for each study. We then calculated study-specific and pooled odds ratios (OR) and $95 \%$ confidence intervals (CI) assuming allele and genotype models. We also calculated pooled ORs and $95 \%$ CIs based on study-specific effect estimates for the allele model. We included five studies
\end{abstract}

M. Schürks $(\varangle) \cdot$ P. M. Rist · T. Kurth

Division of Preventive Medicine, Department of Medicine,

Brigham and Women's Hospital, Harvard Medical School, 900 Commonwealth Avenue East, 3rd Floor, Boston,

MA 02215-1204, USA

e-mail: mschuerks@ rics.bwh.harvard.edu

P. M. Rist · T. Kurth

Department of Epidemiology, Harvard School of Public Health,

Boston, USA

T. Kurth

INSERM Unit 708-Neuroepidemiology, Paris, France

T. Kurth

Faculty of Medicine, Pierre et Marie Curie University,

Paris, France

M. Schürks

Department of Neurology, University Hospital Essen,

Essen, Germany
OR

investigating the association between the STin2 VNTR polymorphism and migraine. Results from the allele model suggested a protective effect against migraine for the STin2.9 and STin2.10 alleles compared to the STin2.12 allele among populations of European descent, which however was not significant. Results from the genotype model indicated a significant $\sim 25 \%$ reduced risk for migraine among carriers of the 10/12 genotype compared with carriers of the 12/12 genotype among all study populations ( $\mathrm{OR}=0.76,95 \%$ CI $0.60-0.97)$ for any migraine, which was more pronounced among populations of European descent $(\mathrm{OR}=0.68,95 \%$ CI $0.53-0.87)$. Results for migraine with and without aura were of similar magnitude, but were not statistically significant. Our results suggest a protective effect of non-STin2.12 alleles compared to STin2.12 alleles, respectively, 10/12 and 10/10 genotypes compared to the 12/12 genotype against migraine among populations of European descent. Associations in nonEuropean populations may differ.

Keywords Migraine - Serotonin transporter - SLC6A4 . STin2 VNTR $\cdot$ Meta-analysis

\begin{tabular}{|c|c|}
\hline Abbreviations & \\
\hline SLC6A4 & Serotonin transporter \\
\hline Bp & Base pair \\
\hline STin2 VNTR polymorphism & $\begin{array}{l}\text { Polymorphism consisting } \\
\text { of a } 17 \mathrm{bp} \text { variable number } \\
\text { of tandem repeats in intron } \\
2 \text { of the SLC6A4 gene }\end{array}$ \\
\hline OR & Odds ratio \\
\hline CI & Confidence interval \\
\hline MA & Migraine with aura \\
\hline MO & Migraine without aura \\
\hline
\end{tabular}




$\begin{array}{ll}\text { IHS } & \text { International Headache } \\ & \text { Society } \\ d f & \text { Degree of freedom } \\ \text { HWE } & \text { Hardy-Weinberg } \\ & \text { equilibrium } \\ \text { SNP } & \text { Single nucleotide } \\ \text { polymorphism }\end{array}$

\section{Introduction}

Migraine is a common headache disorder affecting 10$20 \%$ of the population, women three to four times more often than men [1]. Up to one-third of migraine patients experience an aura prior to or during the migraine headache.

Migraine is viewed as an inherited brain disorder, characterized by neurotransmitter imbalances leading to neuronal dysfunctions, which then present with recurrent headache attacks and combinations of gastrointestinal and autonomic nervous system symptoms [1]. The neurotransmitter serotonin appears to play a pivotal role and alterations in serotonin metabolism and in the processing of central serotonin-mediated responses have been described as typical for migraineurs [2]. Following axonal release, serotonin action is rapidly terminated by presynaptic reuptake [3] through the serotonin transporter SLC6A4 [4]. Furthermore, SLC6A4 is predominantly expressed in the brainstem and midbrain [5], areas implicated in migraine pathophysiology.

A polymorphism in intron 2 of the SLC6A4 gene has been described consisting of a $17 \mathrm{bp}$ variable number of tandem repeats (termed STin2 VNTR). This polymorphism involves two major alleles (termed 'STin2.10' and 'STin2.12') corresponding to 10 or 12 repeat units [6]. In addition, low-frequency alleles (termed 'STin2.9' and 'STin2.7') have been described including nine and seven repeat units [7]. While the biological function of this polymorphism is unclear, STin2.12 has been reported to possess greater transcriptional activity than STin2.10 [8].

A number of studies investigated the association between the STin2 VNTR polymorphism and migraine, with varying results. Some reported altered allelic or genotypic distribution among patients with any migraine [9], migraine with aura (MA) [10-12] or migraine without aura (MO) [10]. Others did not find an association [13].

We sought to summarize the current data on the association between the SLC6A4 STin2 VNTR polymorphism and migraine including MA and MO by systematically reviewing the literature and performing pooled and metaanalyses.

\section{Methods}

Selection of studies

We followed the guidelines for systematic reviews of genetic association studies [14]. Two investigators (M.S., P.M.R.) independently searched MEDLINE, EMBASE and Science Citation Index from inception to September 2009, combining text words and MESH terms, where appropriate, for serotonin and serotonin transporter ("serotonin plasma membrane transport proteins", "serotonin transporter", "serotonin" or "SLC6A4") with terms for genetic variations ("gene", "polymorphism" or "genetic variation") and terms for headache and migraine ("headache", "headache disorders", "migraine" or "migraine disorders"). The search terms were combined with the "explode" feature where applicable. We considered full articles without language restrictions. In addition, we manually searched the reference list of all primary articles and review articles.

A priori, we defined the following criteria for inclusion:

1. Studies must have a cross-sectional, case-control or cohort design and must be published as full papers.

2. Authors must investigate patients with migraine, diagnosed according to the criteria of the International Headache Society (IHS) $[15,16]$ and healthy control subjects.

3. Authors must provide information on genotype frequencies of the SLC6A4 VNTR STin2 polymorphism or sufficient data to calculate these.

4. In studies with overlapping cases and/or controls, the largest study with extractable data was included.

In a first step, two investigators (M.S., T.K.) by consensus identified all studies not meeting any of the prespecified criteria by screening the title and abstracts. These studies were excluded. In a second step, the same investigators evaluated the remaining studies in their entirety. Studies were excluded if they did not meet all criteria.

\section{Data extraction}

Two investigators (M.S., P.M.R.) independently extracted data from the published studies and entered them in a customized database. Disagreements were resolved by consensus. The extracted data included authors and title of study, year of publication, country of origin, ethnicity of population investigated, setting (clinic vs. population), study design, genotyping method, migraine status (any migraine, MA, MO), age range and gender of study participants, study size, allele and genotype frequencies, and information on additional genetic variants as well as genegene and gene-environment interactions, if investigated. If 
not given, genotype frequencies were calculated where possible. We did not contact the authors to collect further information.

\section{Statistical analysis}

In contrast to single nucleotide polymorphisms, which are characterized by two alleles and three genotypes, the SLC6A4 STin2 VNTR polymorphism is characterized by four alleles [6, 7]. Although studies in migraine have only reported the STin2.9, STin2.10 and STin2.12 alleles, it still precludes employment of simple biological models at the allele or genotype level (additive, dominant, recessive) based on one degree of freedom $(d f)$ tests. Further, modelfree approaches at the genotype level based on 'number of genotypes-1' $d f$ yield more than one odds ratio (OR) from one model. These cannot easily be combined for metaanalysis to obtain single pooled effect estimates, tests statistics, and measures of heterogeneity. Hence, we used two different, but complementary approaches, to investigate the association of the SLC6A4 STin2 VNTR polymorphism and migraine.

In the first approach, we investigated an association at the allele level. For each study, we combined the STin2.9 and STin2.10 alleles and compared these to the more frequent STin2.12 alleles, as done in a previous metaanalysis [17]. This approach investigates whether an excess of alleles in one of the two groups alters the risk for migraine. We used logistic regression to calculate odds ratios (ORs) and 95\% confidence intervals (CIs) for each study for the association between alleles of the SLC6A4 STin2 VNTR polymorphism and migraine. We then weighted the $\log$ of the ORs by the inverse of their variance to obtain pooled estimates. We ran random effects models, which include assumptions about the variability between studies. We performed the DerSimonian and Laird Q test for heterogeneity and also calculated the $I^{2}$ statistic for each analysis [18]. This statistic describes the percentage of total variation across studies that is due to heterogeneity rather than chance (25\%: low, 50\%: medium, 75\%: high heterogeneity). We used Galbraith plots to visually examine the impact of individual studies on the overall homogeneity test statistics. We evaluated potential publication bias visually by examining for possible skewness in funnel plots [19] and statistically with the methods described by Begg and Mazumdar [19] and Egger [20].

The second approach was performed at the genotype level. Since one of the studies [12] only presented combined data for the very infrequent genotypes, we also combined these genotypes in the other studies for further analyses ('other genotypes': STin2.9/STin2.10 and STin2.9/STin2.12). We did not further combine any of the other genotypes. We then pooled genotype data from the studies. Finally, we used logistic regression analysis to evaluate the association between pooled genotypes of the SLC6A4 STin2 VNTR polymorphism and migraine. We created indicator variables for each genotype; the most frequent genotype STin2.12/STin2.12 served as reference (3 $d f$ test). We calculated odds ratios (ORs) and 95\% confidence intervals (CIs) for each of the other observed genotypes.

We also investigated Hardy-Weinberg equilibrium (HWE) in each study and in the pooled data, considering the frequent alleles (STin2.10 and STin2.12).

The genotype-based approach has two advantages. Firstly, it is biologically more meaningful, since the genotype as opposed to the allele is the biological unit characterizing an individual. Secondly, it makes no assumption about the underlying biological model (modelfree) allowing for non-linear effects and thus yields effect estimates for each genotype compared to the reference.

In both approaches, we investigated any migraine, MA or MO. We considered $p$ values $<0.05$ as statistically significant. All analyses were performed using SAS version 9.1 (SAS Institute Inc, Cary, NC) and STATA 10.1 (Stata, College Station, TX, USA). Since we only utilized previously published data, we did not obtain the approval of an ethics committee or a written informed consent.

All authors had access to all of the data.

\section{Results}

For ease of readability, genotypes will be referred to by the number of tandem repeats from here on. For example, STin2.12/STin2.12 will be abbreviated as 12/12, STin2.10/ STin2.12 as 10/12 and STin2.10/STin2.10 as 10/10.

Figure 1 summarizes the process of identifying eligible studies. After title and abstract evaluation, we were left with 18 studies [9-13, 21-33]. We excluded 13 more studies [21-33] after evaluating the full paper versions of the remaining articles and were left with 5 studies for this analysis [9-13].

\section{Study characteristics}

Table 1 summarizes the characteristics of the five included studies. Four studies were performed in populations of European descent [10-13] and one in a Turkish population [9]. Four studies, each, presented results for any migraine $[9,10,12,13]$ and MA [10-13] and three for MO [10, 12, 13]. All studies investigated only mixed female and male populations, had a case-control design and used standard polymerase chain reaction genotyping methods. 
Fig. 1 Process of identifying studies

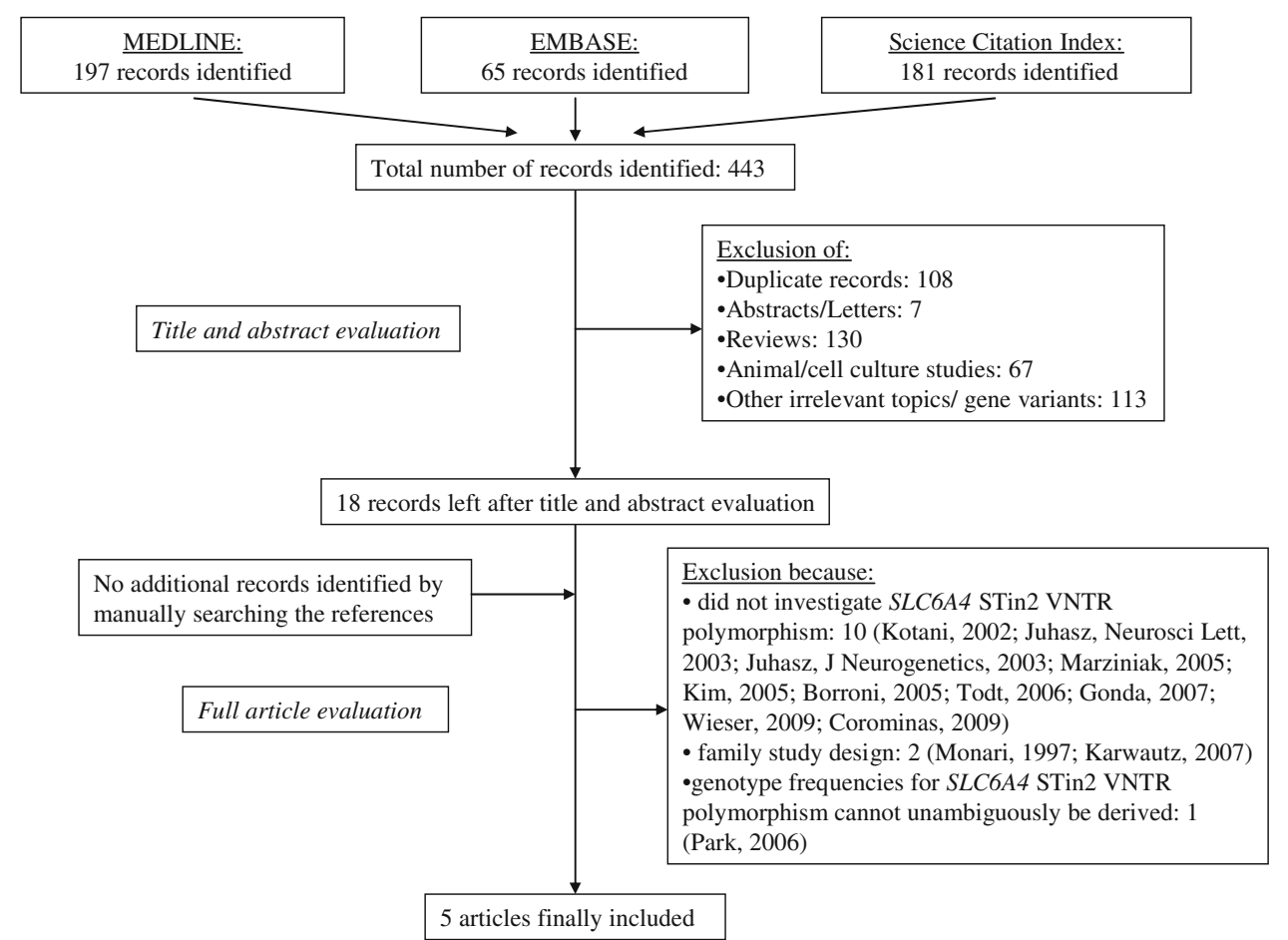

The allele and genotype frequencies for the SLC6A4 STin2 VNTR polymorphism for migraineurs and controls in each of the included studies are summarized in Table 2.

Table 3 summarizes for each of the studies the ORs (95\% CI) for the association between the SLC6A4 STin2 VNTR polymorphism and migraine assuming allele and genotype models as well as $p$ values for the HWE in the controls. Genotype distributions in two control study populations deviated from HWE $[9,13]$. Table 4 summarizes results from the pooled and meta-analyses based on an allele model and Table 5 a pooled analysis based on a genotype model.

\section{Association between the SLC6A4 STin2 VNTR} polymorphism and migraine

In the allele model, some of the effect estimates from individual studies suggested a reduced risk for any migraine [10, 12], MA [10-12] or MO [10] among carriers of the STin2.9 and STin2.10 alleles compared to carriers of the STin2.12 allele (Table 3). However, none of the results were statistically significant. In contrast, the study on a Turkish population suggested a significantly increased risk for any migraine $(\mathrm{OR}=2.09 ; 95 \%$ CI 1.19-3.67) [9].

Results from the genotype model suggested a reduced risk of the 10/12 and 10/10 genotypes for any migraine [10, 12], MA [10, 12] or MO [10] compared with the $12 / 12$ genotype. However, the results only became statistically significant for all three migraine categories for the 10/12 genotype in one study [10] (Table 2). There was no clear pattern of association of the 'other genotypes' with migraine, likely because they are so rare, which is also reflected by the wide confidence intervals. In contrast, the Turkish study [9] suggested a significantly threefold increased risk of any migraine for carriers of the 10/12 and $10 / 10$ genotypes, which was very similar for both genofor any of the genotypes with MA [11], likely due to the small sample size. Another study [13] did not show an association of any of the genotypes with any of the migraine categories in either the allele or the genotype model.

The effect estimates based on the allele model from the pooled and the meta-analyses pointed toward a protective effect against any migraine, MA or MO for the STin2.9 and STin2.10 alleles compared to the STin2.12 allele among populations of European descent (Table 4). ORs from both analyses were very similar; however, none of the results was statistically significant. Heterogeneity among all studies investigating any migraine was medium $\left(I^{2}=70.4 \%\right)$. This was attributable to the Turkish study [9]; analyses of studies only among populations of European descent did not indicate any heterogeneity. Begg's test and Egger's test did not indicate publication bias among studies in populations of European descent, while Egger's test suggested that there might be some publication bias among studies investigating MO $(p=0.01)$.

Our pooled analyses based on a genotype model suggest a $\sim 25 \%$ reduced risk for migraine among carriers of the types. One study did not show a clear pattern of association 
Table 1 Characteristics of included studies investigating the association between the SLC6A4 STin2 VNTR polymorphism and migraine

\begin{tabular}{|c|c|c|c|c|c|c|c|c|}
\hline \multirow[t]{2}{*}{ Author and year } & \multirow[t]{2}{*}{ Country } & \multirow[t]{2}{*}{ Setting } & \multirow[t]{2}{*}{ Population } & \multicolumn{4}{|c|}{ Study size with genotypic information } & \multirow[t]{2}{*}{ Comment } \\
\hline & & & & Controls & Any migraine & MA & MO & \\
\hline Ogilvie [10] & Denmark & Population & Mixed & 133 & 285 & 94 & 173 & \\
\hline Lea [13] & Australia & Population & Mixed & 141 & 148 & 81 & 67 & $\begin{array}{l}\text { Other polymorphisms investigated: in } \\
\text { dopamine beta-hydroxylase gene } \\
(D B H) \text { and dopamine receptor } 2 \\
\text { gene }(D R D 2) \text {. }\end{array}$ \\
\hline Yilmaz [9] & Turkey & NS & Mixed & 79 & 37 & - & - & $\begin{array}{l}\text { Other polymorphisms investigated: } \\
\text { SLC6A4 5-HTTLPR. }\end{array}$ \\
\hline Racchi [11] & Italy & Clinic & Mixed & 32 & - & 44 & - & $\begin{array}{l}\text { Other polymorphisms investigated: } \\
\text { HTR1B } 261 \mathrm{~T}>\mathrm{G}, \text { HTR } 1 B 861 \\
\mathrm{G}>\mathrm{C}, \text { HTR } 2 \mathrm{C} 68 \mathrm{G}>\mathrm{C} \text {. } \\
\text { MA patients were compared to } \\
\text { unaffected family members and } \\
\text { unrelated controls. For the present } \\
\text { analysis, only data from MA patients } \\
\text { and unaffected controls are } \\
\text { considered. }\end{array}$ \\
\hline Szilagyi [12] & Hungary & Clinic & Mixed & 464 & 87 & 38 & 49 & $\begin{array}{l}\text { Other polymorphisms investigated: } \\
\text { SCL6A4 5-HTTLPR. } \\
\text { Cases were children and adolescents; } \\
\text { controls were high school and } \\
\text { university students. }\end{array}$ \\
\hline \multicolumn{4}{|c|}{ Total number of subjects } & 849 & 557 & 257 & 289 & \\
\hline
\end{tabular}

$M A$ migraine with aura, $M O$ migraine without aura, $N S$ not specified

Table 2 Allele and genotype frequencies for the SLC6A4 STin2 VNTR polymorphism

\begin{tabular}{|c|c|c|c|c|c|c|c|c|c|}
\hline \multirow[t]{2}{*}{ Author } & \multirow[t]{2}{*}{ Disease status } & \multirow[t]{2}{*}{ Study size } & \multicolumn{3}{|c|}{ Allele frequencies, $n(\%)$} & \multicolumn{4}{|c|}{ Genotype frequencies, $n(\%)$} \\
\hline & & & STin 2.9 & STin 2.10 & STin 2.12 & Other $^{\mathrm{a}}$ & $\begin{array}{l}\text { STin2.10/ } \\
\text { STin2.10 }\end{array}$ & $\begin{array}{l}\text { STin2.10/ } \\
\text { STin2.12 }\end{array}$ & $\begin{array}{l}\text { STin2.12/ } \\
\text { STin2.12 }\end{array}$ \\
\hline \multirow[t]{4}{*}{ Ogilvie [10] } & Controls & 133 & $3(1.1)$ & $107(40.2)$ & $156(58.7)$ & $3(2.3)$ & $19(14.3)$ & $68(51.1)$ & $43(32.3)$ \\
\hline & Any migraine & 285 & $14(2.5)$ & $187(32.8)$ & $369(64.7)$ & $14(4.9)$ & $38(13.3)$ & $105(36.8)$ & $128(44.9)$ \\
\hline & MA & 94 & $6(3.2)$ & $66(35.1)$ & $116(61.7)$ & $6(6.4)$ & $15(16.0)$ & $32(34.0)$ & $41(43.6)$ \\
\hline & MO & 173 & $6(1.7)$ & $113(32.7)$ & $227(65.6)$ & $6(3.5)$ & $22(12.7)$ & $68(39.3)$ & $77(44.5)$ \\
\hline \multirow[t]{4}{*}{ Lea [13] } & Controls & 141 & $4(1.4)$ & $112(39.7)$ & $166(58.9)$ & $4(2.8)$ & $33(23.4)$ & $45(31.9)$ & $59(41.8)$ \\
\hline & Any migraine & 148 & $5(1.7)$ & $116(39.2)$ & $175(59.1)$ & $5(3.4)$ & $34(23.0)$ & $46(31.1)$ & $63(42.6)$ \\
\hline & MA & 81 & $3(1.9)$ & $64(39.5)$ & 95 (58.6) & $3(3.7)$ & $19(23.5)$ & $25(30.9)$ & $34(42.0)$ \\
\hline & MO & 67 & $2(1.5)$ & $52(38.8)$ & $80(59.7)$ & $2(3.0)$ & $15(22.4)$ & $21(31.3)$ & $29(43.3)$ \\
\hline \multirow[t]{2}{*}{ Yilmaz [9] } & Controls & 79 & $0(0.0)$ & $53(33.5)$ & $105(66.5)$ & $0(0.0)$ & $14(17.7)$ & 25 (31.6) & $40(50.6)$ \\
\hline & Any migraine & 37 & $0(0.0)$ & $38(51.4)$ & 36 (48.6) & $0(0.0)$ & $10(27.0)$ & 18 (48.6) & $9(24.3)$ \\
\hline \multirow[t]{2}{*}{ Racchi [11] } & Controls & 32 & $2(3.1)$ & $30(46.9)$ & $32(50.0)$ & $2(6.3)$ & $9(28.1)$ & $12(37.5)$ & $9(28.1)$ \\
\hline & MA & 44 & $0(0.0)$ & $35(39.8)$ & $53(60.2)$ & $0(0.0)$ & $3(6.8)$ & $29(65.9)$ & $12(27.3)$ \\
\hline \multirow[t]{4}{*}{ Szilagyi [12] } & Controls & 464 & $13(1.4)$ & 340 (36.6) & $575(62.0)$ & $13(2.8)$ & $59(12.7)$ & $220(47.4)$ & $172(37.1)$ \\
\hline & Any migraine & 87 & $3(1.7)$ & 55 (31.6) & $116(66.7)$ & $3(3.4)$ & $8(9.2)$ & $38(43.7)$ & $38(43.7)$ \\
\hline & MA & 38 & $2(2.6)$ & $19(25.0)$ & $55(72.4)$ & $2(5.3)$ & $3(7.9)$ & $13(34.2)$ & $20(52.6)$ \\
\hline & $\mathrm{MO}$ & 49 & $1(1.0)$ & $36(36.7)$ & $61(62.2)$ & $1(2.0)$ & $5(10.2)$ & $25(51.0)$ & $18(36.7)$ \\
\hline
\end{tabular}

$M A$ migraine with aura, $M O$ migraine without aura

${ }^{a}$ STin2.9/STin2.10 and STin2.9/STin2.12

10/12 genotype compared with carriers of the 12/12 genotype (Table 5). The pooled ORs (95\% CI) among all study populations were $0.76(0.60-0.97)$ for any migraine.
When we confined our analysis to populations of European descent, this effect appeared more pronounced $(\mathrm{OR}=0.68,95 \%$ CI $0.53-0.87)$. The results for MA 


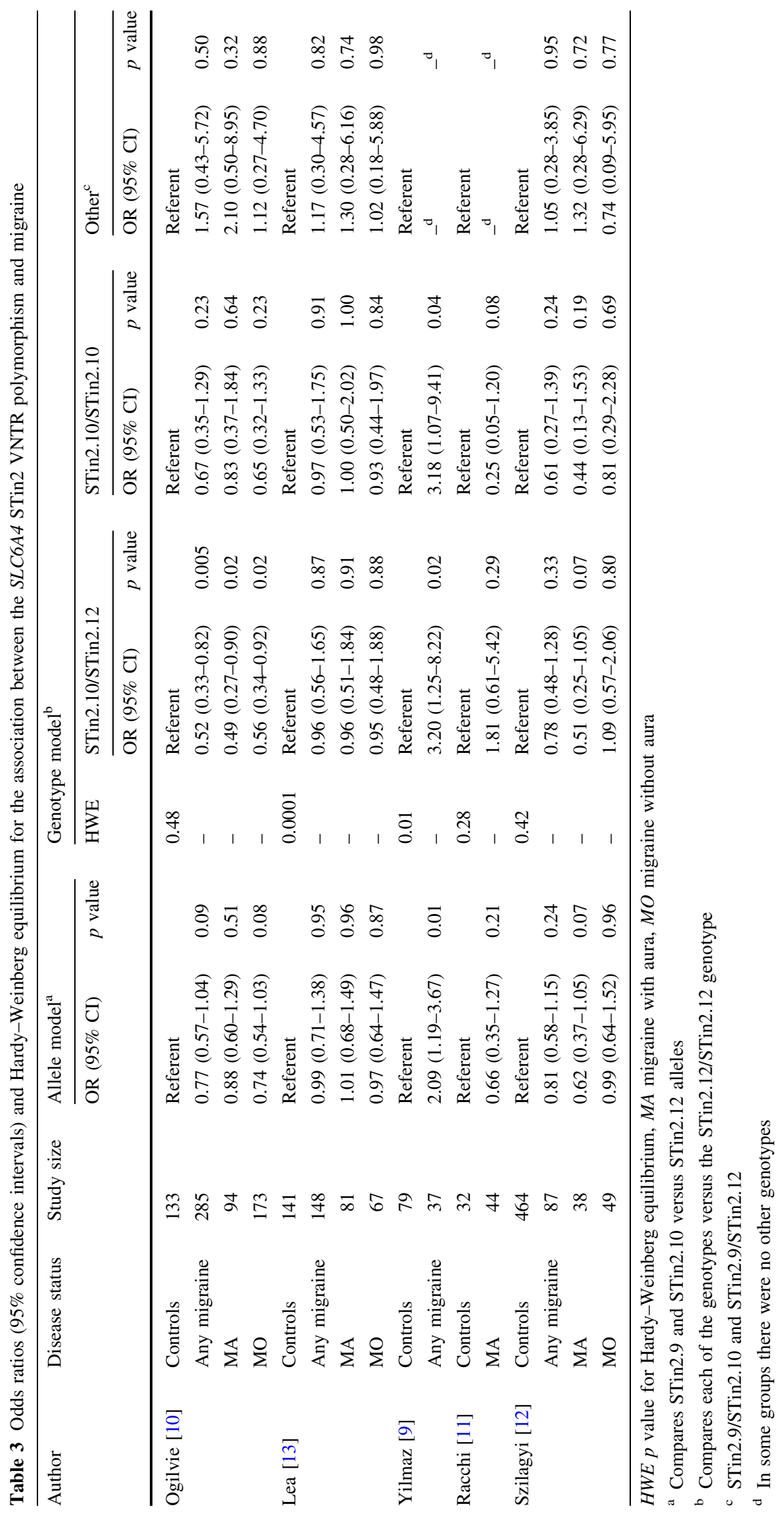


Table 4 Allele model: pooled and meta-analyses of the association between the SLC6A4 STin2 VNTR polymorphism and migraine

\begin{tabular}{|c|c|c|c|c|c|c|c|c|c|c|}
\hline \multirow{3}{*}{$\begin{array}{l}\text { Migraine } \\
\text { category }\end{array}$} & \multirow[t]{3}{*}{ Study populations } & \multirow{3}{*}{$\begin{array}{l}\text { No. of } \\
\text { studies }\end{array}$} & \multirow{3}{*}{$\begin{array}{l}\text { Pooled analysis } \\
\text { Odds ratio }^{\mathrm{a}} \\
(95 \% \mathrm{CI})\end{array}$} & \multicolumn{7}{|l|}{ Meta-analysis } \\
\hline & & & & \multirow{2}{*}{$\begin{array}{l}\text { Odds ratio } \\
(95 \% \text { CI })\end{array}$} & \multicolumn{4}{|c|}{ Heterogeneity } & \multicolumn{2}{|c|}{ Publication bias } \\
\hline & & & & & $Q$ & $d f$ & $p$ value & $I^{2}$ in $\%$ & $\begin{array}{l}p \text { value, } \\
\text { Begg }\end{array}$ & $\begin{array}{l}p \text { value, } \\
\text { Egger }\end{array}$ \\
\hline \multirow[t]{2}{*}{ Any migraine } & All $[9,10,12,13]$ & 4 & $0.95(0.81-1.11)$ & $1.00(0.72-1.41)$ & 10.1 & 3 & 0.02 & 70.4 & 0.17 & 0.045 \\
\hline & European descent $[10,12,13]$ & 3 & $0.89(0.76-1.05)$ & $0.85(0.70-1.02)$ & 1.3 & 2 & 0.54 & 0 & 0.60 & 0.63 \\
\hline MA & European descent $[10-13]^{\mathrm{b}}$ & 4 & $0.93(0.76-1.14)$ & $0.83(0.66-1.05)$ & 2.7 & 3 & 0.44 & 0 & 0.50 & 0.17 \\
\hline MO & European descent $[10,12,13]^{\mathrm{b}}$ & 3 & $0.88(0.72-1.08)$ & $0.86(0.69-1.08)$ & 1.5 & 2 & 0.48 & 0 & 0.12 & 0.01 \\
\hline
\end{tabular}

MA migraine with aura, $M O$ migraine without aura

${ }^{a}$ STin2.9 and STin2.10 alleles were grouped together and compared to STin2.12 as the reference

b There are no studies available for MA and MO among populations of non-European descent

Table 5 Genotype model: pooled analysis of the association between the SLC6A4 STin2 VNTR polymorphism and migraine

\begin{tabular}{|c|c|c|c|c|c|c|c|c|c|}
\hline \multirow{2}{*}{$\begin{array}{l}\text { Migraine } \\
\text { category }\end{array}$} & \multirow[t]{2}{*}{ Study populations } & \multirow{2}{*}{$\begin{array}{l}\text { No of } \\
\text { studies }\end{array}$} & \multirow[t]{2}{*}{ HWE } & \multicolumn{2}{|l|}{$10 / 12$} & \multicolumn{2}{|l|}{$10 / 10$} & \multicolumn{2}{|l|}{ Other $^{\mathrm{a}}$} \\
\hline & & & & $\begin{array}{l}\text { Odds ratio } \\
(95 \% \text { CI })\end{array}$ & $p$ value & $\begin{array}{l}\text { Odds ratio } \\
(95 \% \text { CI })\end{array}$ & $p$ value & $\begin{array}{l}\text { Odds ratio }^{\mathrm{b}} \\
(95 \% \mathrm{CI})\end{array}$ & $p$ value \\
\hline \multirow[t]{2}{*}{ Any migraine } & All $[9,10,12,13]$ & 4 & 0.18 & $0.76(0.60-0.97)$ & 0.03 & $0.95(0.69-1.31)$ & 0.75 & $1.45(0.77-2.72)$ & 0.25 \\
\hline & European descent $[10,12,13]$ & 3 & 0.58 & $0.68(0.53-0.87)$ & 0.002 & $0.86(0.62-1.21)$ & 0.39 & $1.32(0.70-2.47)$ & 0.39 \\
\hline MA & European descent $[10-13]^{\mathrm{c}}$ & 4 & 0.40 & $0.76(0.55-1.04)$ & 0.09 & $0.88(0.58-1.34)$ & 0.56 & $1.32(0.62-2.82)$ & 0.47 \\
\hline MO & European descent $[10,12,13]^{\mathrm{c}}$ & 3 & 0.58 & $0.76(0.56-1.02)$ & 0.07 & $0.84(0.55-1.26)$ & 0.40 & $0.99(0.44-2.25)$ & 0.99 \\
\hline
\end{tabular}

$H W E p$ value for Hardy-Weinberg equilibrium, $M A$ migraine with aura, $M O$ migraine without aura

${ }^{a}$ STin2.9/STin2.10 and STin2.9/STin2.12

b Genotype 12/12 was used as the reference

c There are no studies available for MA and MO among populations of non-European descent

$(\mathrm{OR}=0.76 ; 95 \% \mathrm{CI}$ 0.55-1.04) and $\mathrm{MO}(\mathrm{OR}=0.76$; 95\% CI 0.56-1.02) were of similar magnitude, but did not reach statistical significance. While the ORs for the 10/10 genotype also pointed toward a protective effect, they were larger and not statistically significant. In contrast, the 'other genotypes' appeared to increase the risk for any migraine and MA, but not MO.

Sensitivity analyses

We performed two kinds of sensitivity analyses.

Firstly, we created Galbraith plots based on the ORs from the allele models (Table 3). The plot for studies investigating any migraine identified the Turkish study [9] as an important source of heterogeneity, since the OR fell outside the margin set by the $z$ score \pm 2 standard deviations. An analysis excluding that study was identical to our analysis among populations of European descent. The plots for MA and MO did not identify any of the studies as significant sources of heterogeneity.

Secondly, we re-ran all pooled and meta-analyses by excluding studies where the genotype distribution deviated from HWE in the control group [9, 13]. The effect estimates for the allele model from the pooled and the meta-analyses were all slightly lower. Results from the pooled analyses remained insignificant; the ORs $(95 \% \mathrm{CI})$ for any migraine were $0.84(0.70-1.02)$, for MA 0.88 (0.69-1.13), and for MO 0.86 (0.68-1.07). Results from the meta-analysis were significant for any migraine $(\mathrm{OR}=0.79,95 \% \mathrm{CI} 0.63-0.99)$ and marginally significant for MA $(\mathrm{OR}=0.76,95 \%$ CI $0.57-1.00 ; p=0.05)$. The OR (95\% CI) for MO was 0.83 (0.63-1.09). The results from the genotype model remained very similar. For example, the OR (95\% CI) for the 10/12 genotype was 0.64 $(0.48-0.86)$ for any migraine, $0.76(0.53-1.09)$ for MA and 0.73 (0.52-1.02) for MO compared to the 12/12 genotype.

\section{Discussion}

The main results from these pooled and meta-analyses on the association between the SLC6A4 STin2 VNTR polymorphism and migraine are that non-STin2.12 alleles compared to STin2.12 alleles and 10/12 and 10/10 genotypes compared to the $12 / 12$ genotype appear to protect against migraine among populations of European descent. 
Results from the allele analyses were not statistically significant. Results from genotype analyses suggested the smallest effect estimates for the 10/12 genotype translating into a $\sim 25 \%$ reduced risk and became statistically significant for the largest group of patients with any migraine. The effect estimates were similar for any migraine, MA and MO. In contrast, associations may differ in nonEuropean populations, as suggested by a Turkish study [9] showing a threefold increased risk for any migraine among carriers of the 10/12 and 10/10 genotypes.

Migraine has a clear genetic component with a heritability as high as 50\% [34]. However, identifying genetic markers for common forms of migraine has been difficult [35].

Serotonin plays a pivotal role in migraine [2] and a dysfunctional serotonergic system agrees with pathophysiological models of a cortical dysbalance [36] and treatment success of triptans [37]. Among the main features in migraineurs are changes in serotonin metabolism and in the processing of central serotonin-mediated responses [2]. Synaptic serotonin is moved to the intracellular space by the serotonin transporter SLC6A4 and two polymorphisms in the SLC6A4 gene have been investigated with regard to their association with migraine: the 5-HTTLPR and the STin2 VNTR polymorphisms. In a recent meta-analysis on the association of the 5-HTTLPR polymorphism and migraine, we did not find an overall association among Europeans and Asians; however, gender and migraine aura status may have modifying roles among Europeans [38]. Similar to studies on the 5-HTTLPR polymorphism, studies on the association between the STin2 VNTR polymorphism and migraine came to conflicting results. Some have reported an altered allelic or genotypic distribution among patients with any migraine [9], MA [10-12] or MO [10], while others did not find an association [13]. This may in part be due to differences in sample size and study characteristics. In addition, it is unclear whether only a specific combination of alleles, i.e., a single genotype, or the simple presence of one allele, i.e., multiple genotypes, might alter the risk for migraine.

Results from our analyses indicating a protective role against migraine for non-STin2.12 alleles, respectively, for 10/12 and 10/10 genotypes of the STin2 VNTR polymorphism in populations of European descent became only statistically significant for the association between the 10/12 genotype and any migraine. However, we are confident that this reflects a true association and is not a false positive signal for two reasons. Firstly, results from the allele and genotype models agree by pointing toward the same direction of a protective effect of non-STin2.12 alleles/non12/12 genotypes. Second, our sensitivity analyses suggest similar or even smaller effect estimates and $p$ values.
Employing a genotype model in addition to an allele model yields further valuable information. Firstly, it indicated that both the 10/12 and 10/10 genotypes reduced the risk for migraine compared to the $12 / 12$ genotype. This allows for two possible interpretations. On the one hand, the STin2.10 allele may exert a dominant effect over the STin2.12 allele. The higher ORs and non-significant $p$ values for the $10 / 10$ genotype may be due to the smaller number of 10/10 than 10/12 genotypes (Table 2). Alternatively, the protective effect may only occur with the 10/ 12 genotype, as suggested by the statistical significance of the results. It may be speculated that an unequal number of tandem repeats on the two chromosomes (heterozygotes) impairs transporter function, which does not occur for homozygotes. Examples from other gene variants exist, for example the GNB3 825C $>$ T polymorphism [39], where the largest association is seen among carriers of heterozygous genotypes. Secondly, providing estimates for genotypes, as opposed to alleles, is biologically more meaningful, since the genotype is the genetic unit characterizing each individual. Thirdly, the $\sim 25 \%$ reduced risk for migraine of the 10/12 genotype appears moderate; however, it is in keeping with migraine being a complex disorder. This means that multiple genetic (and environmental) factors with small to moderate effects determine the susceptibility for migraine.

Results for the 'other genotypes' (9/10 and 9/12) suggested that the risk for migraine may be increased for any migraine and MA (Table 5). However, caution is warranted since the frequencies of the 'other genotypes' are very rare rendering the results susceptible to minor alterations in genotype distribution.

The functional implications of the STin2 VNTR polymorphism are not well understood. Expression studies have shown that the STin2.10 and STin2.12 alleles enhance transcriptional activity, Stin2.10 significantly less than STin2.12 [8]. We may speculate that STin2.10 leads to a lower number of SLC6A4 transporters, hence less serotonin reuptake and more synaptic (maybe 'normal') serotonin activity compared to the STin2.12 allele. This may reduce the risk for migraine as also suggested by our analyses. However, functional investigations of the platelet serotonin transporter do not agree, since they show that serotonin uptake is unaltered by the STin2 VNTR polymorphism [40].

The following aspects of our meta-analysis need to be considered. First, migraine is a heterogeneous disorder with a wide clinical spectrum [35]. Patients with different clinical phenotypes have been diagnosed as having migraine, and even strict classification according to IHS criteria [15, 16] may not sufficiently capture this variability and may be a source of misclassification in all studies. Second, the total number of studies identified was five, which limits the statistical power. Hence, a larger sample size than available from all the studies combined might be necessary to 
improve precision of our results. While the systematic review part allows for an overview of the available studies including individual results, the meta-analytic part also facilitates evaluation of magnitude and direction of pooled effect estimates including sources of heterogeneity. Third, SLC6A4 is a large polymorphic gene comprising $37,810 \mathrm{bp}$ organized into 15 exons and 14 introns with 380 single nucleotide polymorphisms (SNPs) reported [41, 42]. Some of these SNPs may be associated with migraine [43]. Hence, in addition to the SLC6A4 STin2 VNTR and 5HTTLPR polymorphisms, these SNPs may also affect transporter production and function. Fourth, serotonin's role in migraine is not just determined by transporter activity, but also by its functional effect at the receptor level. Serotonin receptor genes are likewise polymorphic and some of these variants may be associated with migraine [22]. Fifth, in addition to serotonin, other neurotransmitters such as dopamine, orexin and glutamate are important in migraine pathophysiology [44]. Hence, migraine susceptibility is a function of the interaction between various neurotransmitters, which again is determined by the interaction of various genetic variants. Sixth, migraine susceptibility is different between women and men, as indicated by the higher prevalence among women [45]. However, we had no means to investigate a gender differential genetic effect of the STin2 VNTR polymorphism, since all studies were performed in mixed female and male populations and gender-stratified genotypic information was unavailable. Seventh, associations with migraine may differ by ethnicity, especially since the genotype distribution of the STin2 VNTR polymorphism shows ethnic differences [46, 47]. The available studies provide limited indication for that. While the 10/12 and 10/10 genotypes appeared to protect against migraine in populations of European descent, one Turkish study [9] reported an increased risk. Eighth, genotypes deviated from HWE in two studies [9, 13]. However, sensitivity analyses after excluding these studies did not alter our results. Finally, we only used extractable data from the papers. One paper did not unequivocally indicate genotype frequencies for each of the STin2 VNTR genotypes [31]. The study was excluded. However, the authors only investigated $\mathrm{MO}$; hence, this study would not have altered our results for any migraine and MA. In addition, the authors reported a higher frequency of the 12/12 genotype in patients with MO, which corresponds with our results. Thus, including this study would likely not have changed our results for MO either.

\section{Conclusion}

The 10/12 genotype of the SLC6A4 STin2 VNTR polymorphism translates into a $\sim 25 \%$ reduced risk for any migraine. However, additional studies with large sample sizes of migraineurs and controls seem warranted. Studies should not just be carried out in populations of European descent, but also in non-European populations. In addition to overall results, results should also be presented stratified by gender and migraine aura status. Finally, analyses should focus on main gene effects and gene-gene interactions investigated only if the sample size is reasonably large.

Acknowledgments Dr. Schürks has received an investigator-initiated research grant from the Migraine Research Foundation and honoraria from L.E.K. Consulting for telephone surveys. Dr. Kurth has received investigator-initiated research funding from the French National Research Agency, the National Institutes of Health, Merck, and the Migraine Research Foundation. Further, he is a consultant to i3 Drug Safety and World Health Information Science Consultants, LLC; he has received honoraria from Genzyme, Merck, and Pfizer for educational lectures.

Conflict of interest None.

\section{References}

1. Haut SR, Bigal ME, Lipton RB (2006) Chronic disorders with episodic manifestations: focus on epilepsy and migraine. Lancet Neurol 5:148-157

2. Hamel E (2007) Serotonin and migraine: biology and clinical implications. Cephalalgia 27:1293-1300

3. Rudnick G, Clark J (1993) From synapse to vesicle: the reuptake and storage of biogenic amine neurotransmitters. Biochim Biophys Acta 1144:249-263

4. Ramamoorthy S, Bauman AL, Moore KR, Han H, Yang-Feng T, Chang AS, Ganapathy V, Blakely RD (1993) Antidepressant- and cocaine-sensitive human serotonin transporter: molecular cloning, expression, and chromosomal localization. Proc Natl Acad Sci USA 90:2542-2546

5. Hornung JP (2003) The human raphe nuclei and the serotonergic system. J Chem Neuroanat 26:331-343

6. Lesch KP, Balling U, Gross J, Strauss K, Wolozin BL, Murphy DL, Riederer P (1994) Organization of the human serotonin transporter gene. J Neural Transm Gen Sect 95:157-162

7. Kaiser R, Tremblay PB, Schmider J, Henneken M, Dettling M, Muller-Oerlinghausen B, Uebelhack R, Roots I, Brockmoller J (2001) Serotonin transporter polymorphisms: no association with response to antipsychotic treatment, but associations with the schizoparanoid and residual subtypes of schizophrenia. Mol Psychiatry 6:179-185

8. MacKenzie A, Quinn J (1999) A serotonin transporter gene intron 2 polymorphic region, correlated with affective disorders, has allele-dependent differential enhancer-like properties in the mouse embryo. Proc Natl Acad Sci USA 96:15251-15255

9. Yilmaz M, Erdal ME, Herken H, Cataloluk O, Barlas O, Bayazit YA (2001) Significance of serotonin transporter gene polymorphism in migraine. J Neurol Sci 186:27-30

10. Ogilvie AD, Russell MB, Dhall P, Battersby S, Ulrich V, Smith CA, Goodwin GM, Harmar AJ, Olesen J (1998) Altered allelic distributions of the serotonin transporter gene in migraine without aura and migraine with aura. Cephalalgia 18:23-26

11. Racchi M, Leone M, Porrello E, Rigamonti A, Govoni S, Sironi M, Montomoli C, Bussone G (2004) Familial migraine with aura: association study with 5-HT1B/1D, 5-HT2C, and hSERT polymorphisms. Headache 44:311-317 
12. Szilagyi A, Boor K, Orosz I, Szantai E, Szekely A, Kalasz H, Sasvari-Szekely M, Farkas V (2006) Contribution of serotonin transporter gene polymorphisms to pediatric migraine. Headache 46:478-485

13. Lea RA, Dohy A, Jordan K, Quinlan S, Brimage PJ, Griffiths LR (2000) Evidence for allelic association of the dopamine betahydroxylase gene $(\mathrm{DBH})$ with susceptibility to typical migraine. Neurogenetics 3:35-40

14. Sagoo GS, Little J, Higgins JP (2009) Systematic reviews of genetic association studies. PLoS Med 6:e28

15. (2004) The international classification of headache disorders, 2 nd edn. Cephalalgia 24(Suppl 1):9-160

16. Headache Committee of the International Headache Society (1988) Classification and diagnostic criteria for headache disorders, cranial neuralgias and facial pain. Cephalalgia 8(Suppl 7): $1-96$

17. Fan JB, Sklar P (2005) Meta-analysis reveals association between serotonin transporter gene STin2 VNTR polymorphism and schizophrenia. Mol Psychiatry 10:928-938

18. Higgins JP, Thompson SG, Deeks JJ, Altman DG (2003) Measuring inconsistency in meta-analyses. BMJ 327:557-560

19. Begg CB, Mazumdar M (1994) Operating characteristics of a rank correlation test for publication bias. Biometrics 50:10881101

20. Egger M, Davey Smith G, Schneider M, Minder C (1997) Bias in meta-analysis detected by a simple, graphical test. BMJ 315:629634

21. Borroni B, Brambilla C, Liberini P, Rao R, Archetti S, Gipponi S, Volta GD, Padovani A (2005) Functional serotonin 5-HTTLPR polymorphism is a risk factor for migraine with aura. J Headache Pain 6:182-184

22. Corominas R, Sobrido MJ, Ribasés M, Cuenca-León E, BlancoArias P, Narberhaus B, Roig M, Leira R, López-González J, Macaya A, Cormand B (2009) Association study of the serotoninergic system in migraine in the spanish population. Am J Med Genet B Neuropsychiatr Genet. doi:10.1002/ajmg.b.30972

23. Gonda X, Rihmer Z, Juhasz G, Zsombok T, Bagdy G (2007) High anxiety and migraine are associated with the s allele of the 5HTTLPR gene polymorphism. Psychiatry Res 149:261-266

24. Juhasz G, Zsombok T, Laszik A, Gonda X, Sotonyi P, Faludi G, Bagdy G (2003) Association analysis of 5-HTTLPR variants, 5HT2a receptor gene 102T/C polymorphism and migraine. J Neurogenet 17:231-240

25. Juhasz G, Zsombok T, Laszik A, Jakus R, Faludi G, Sotonyi P, Bagdy G (2003) Despite the general correlation of the serotonin transporter gene regulatory region polymorphism (5-HTTLPR) and platelet serotonin concentration, lower platelet serotonin concentration in migraine patients is independent of the 5HTTLPR variants. Neurosci Lett 350:56-60

26. Karwautz AF, Campos de Sousa S, Wober C, Wagner G, Li T, Konrad A, Zesch HE, Zormann A, Berger G, Wanner C, WoberBingol C, Collier DA (2007) Family-based analysis of serotonin transporter gene polymorphisms in migraine with and without aura. Cephalalgia 27:773-780

27. Kim WK, Kim HS, Kim WJ, Lee KY, Park H, Kim CH, Kim SJ, Choi YC (2005) Serotonin transporter gene polymorphism and migraine in the Korean population. Headache 45:1056-1060

28. Kotani K, Shimomura T, Shimomura F, Ikawa S, Nanba E (2002) A polymorphism in the serotonin transporter gene regulatory region and frequency of migraine attacks. Headache 42:893-895
29. Marziniak M, Mossner R, Schmitt A, Lesch KP, Sommer C (2005) A functional serotonin transporter gene polymorphism is associated with migraine with aura. Neurology 64:157-159

30. Monari L, Mochi M, Valentino ML, Arnaldi C, Cortelli P, De Monte A, Pierangeli G, Prologo G, Scapoli C, Soriani S, Montagna $P$ (1997) Searching for migraine genes: exclusion of $290 \mathrm{cM}$ out of the whole human genome. Ital J Neurol Sci 18:277-282

31. Park JW, Han SR, Yang DW, Kim YI, Lee KS (2006) Serotonin transporter protein polymorphism and harm avoidance personality in migraine without aura. Headache 46:991-996

32. Todt U, Freudenberg J, Goebel I, Heinze A, Heinze-Kuhn K, Rietschel M, Gobel H, Kubisch C (2006) Variation of the serotonin transporter gene SLC6A4 in the susceptibility to migraine with aura. Neurology 67:1707-1709

33. Wieser T, Dresler K, Evers S, Gaul C, König D, Hölzl D, Berger K, Nyholt D, Deufel T (2009) No influence of 5-HTTLPR gene polymorphism on migraine symptomatology, comorbid depression, and chronification. Headache. doi:10.1111/j.1526-4610. 2009.01428.x

34. Kors EE, Vanmolkot KR, Haan J, Frants RR, van den Maagdenberg AM, Ferrari MD (2004) Recent findings in headache genetics. Curr Opin Neurol 17:283-288

35. Wessman M, Terwindt GM, Kaunisto MA, Palotie A, Ophoff RA (2007) Migraine: a complex genetic disorder. Lancet Neurol 6:521-532

36. Coppola G, Pierelli F, Schoenen J (2007) Is the cerebral cortex hyperexcitable or hyperresponsive in migraine? Cephalalgia 27:1427-1439

37. Humphrey PP (2007) The discovery of a new drug class for the acute treatment of migraine. Headache 47(Suppl 1):S10-S19

38. Schürks M, Rist PM, Kurth T (2010) 5-HTTLPR polymorphism in the serotonin transporter gene and migraine: a systematic review and meta-analysis. Cephalalgia. doi:10.1177/0333102410362929

39. Schürks M, Kurth T, Stude P, Rimmbach C, de Jesus J, Jonjic M, Diener HC, Rosskopf D (2007) G protein beta3 polymorphism and triptan response in cluster headache. Clin Pharmacol Ther 82:396-401

40. Kaiser R, Muller-Oerlinghausen B, Filler D, Tremblay PB, Berghofer A, Roots I, Brockmoller J (2002) Correlation between serotonin uptake in human blood platelets with the 44-bp polymorphism and the 17-bp variable number of tandem repeat of the serotonin transporter. Am J Med Genet 114:323-328

41. http://genome.ucsc.edu/

42. http://www.ncbi.nlm.nih.gov/projects/SNP/

43. Bayerer B, Engelbergs J, Savidou I, Boes T, Kuper M, Schorn CF, Wissmann A, Knop D, Diener HC, Limmroth V (2009) Single nucleotide polymorphisms of the serotonin transporter gene in migraine-an association study. Headache. doi: 10.1111/j.1526-4610.2009.01553.x

44. Goadsby PJ, Charbit AR, Andreou AP, Akerman S, Holland PR (2009) Neurobiology of migraine. Neuroscience 161:327-341

45. Lipton RB, Bigal ME (2005) The epidemiology of migraine. Am J Med 118(Suppl 1):3S-10S

46. Gelernter J, Cubells JF, Kidd JR, Pakstis AJ, Kidd KK (1999) Population studies of polymorphisms of the serotonin transporter protein gene. Am J Med Genet 88:61-66

47. Kunugi H, Hattori M, Kato T, Tatsumi M, Sakai T, Sasaki T, Hirose T, Nanko S (1997) Serotonin transporter gene polymorphisms: ethnic difference and possible association with bipolar affective disorder. Mol Psychiatry 2:457-462 